\title{
Schizophreniform Disorder Following Excessive Consumption of Energy Drinks: A Case Report
}

\author{
Iman Mustafa Elhag ${ }^{1}$, Anas Ibn Auf ${ }^{1}$ \\ ${ }^{1}$ Mental Health Hospital, Taif, Saudi Arabia
}

\begin{abstract}
Introduction- Consumption of energy drinks is increasing each year worldwide, especially among young people seeking for assumed power and increased physical and emotional endurance. Energy drinks contain caffeine which has stimulating effects, but its excessive and chronic consumption may cause unwanted effects; physically and mentally. There are some studies reported symptoms of psychotic and mood disorders associated with excessive use of caffeine. We present a case of clear psychotic features in a young female following a four-year history of consuming large amounts of energy drinks. In conclusion, this case suggests an association between excessive use of energy drinks and schizophreniform disorder.
\end{abstract}

Key words: energy drinks; psychotic disorders; Saudi Arabia

Copyright $@ 2021 \mathrm{KBCSM}$, Zagreb

e-mail: apr.kbcsm@gmail.com•www.http://apr.kbcsm.hr

\section{Introduction}

Energy drinks are nonalcoholic beverages which have stimulant effects due to some ingredients; most commonly caffeine, and other components [1]. Consumption of energy drinks started in 1960s in Asia and Europe, then became popular in 1980s with further increase every year worldwide [2]. Marketing of these drinks was promoted by the claim that they enhance physical and emotional abilities and increase concentration [3].There are many different trade names of energy drinks around the world and they vary widely in caffeine content, starting from 50 - $505 \mathrm{mg}$ per can or bottle [2]. Caffeine is most important active ingre-

Correspondence to:

Anas Ibn Auf, MD

Mental Health Hospital, Taif, Saudi Arabia

E-mail: anasibnauf@hotmail.com dient in these drinks, but it is not the only one. There are a non-essential amino acid called Taurine which is found in high amounts ranging from 750 to $1,000 \mathrm{mg}$ per serving, while its amounts in the normal diet are between 40 and $400 \mathrm{mg}$ per day [4]. It has a role in calcium release, so it affects the brain, heart, and skeletal muscle, and these effects may be enhanced by combined caffeine [5].

Although low doses of caffeine may have positive effects, such as moderately elevating mood [6], higher doses may cause unpleasant effects such as: tension, nervousness, anxiety, excitement, irritability, nausea, palpitations, and restlessness [7]. Moreover, heavy caffeine consumption is significantly associated with some psychiatric disorders, including depressive and anxiety disorders [8].

Although it is rare, but it is proved that high doses of caffeine can induce psychotic and 
manic symptoms [9]. There are some studies reported the appearance of psychosis in relation to heavy consumption of energy drinks $[1,10,11]$. We are presenting a new onset of schizophrenia-like symptoms following excessive energy drinks in a young Saudi female.

\section{Summary of the Case}

A 24-year-old lady, single, lives with her grandmother for the last four years. Before that she lived with her parents, brothers and sisters. She was very well until four months back when she was noticed to behave bizarrely, talking to herself, elated in moods, not sleeping at all. The family thought she was responding to auditory hallucinations and probably visual as well.

Her parents gave four years history of her consuming large amounts of energy drinks. They described her taking it in increasing amounts until she lastly reached an average of 4-6 cans per day or even more, and when advised not to take it, she ignored the advice. Her father reported throwing away many cans from the fridge, a month before her admission. He thought that she may become well after that but her condition did not improve.

She does not have a history of psychiatric disorders or other psychoactive substance use. She was born with a heart defect and she underwent open heart surgery at the age of one year, but there is no other medical condition and she is not on long term medications.

Regarding her personal history, the patient was an outcome of a normal full term vaginal delivery, and went through normal milestones. She started school at age of seven, did average in school and left it at 19. At that stage, her father explained that she went to leave with her grandmother as she was getting old, needing someone to help her with daily living. Regarding her premorbid personality, she was described by her family as a happy, sociable person who loved her family and friends and was loved by them.
Her mother is in her late forties, with no history of physical or psychiatric problems. Her father is in his fifties, retired with no medical or psychiatric health condition. Our patient is the eldest of seven siblings, five sisters and two brothers, all are well and healthy. Her youngest sibling is two months old. There is significant positive family history of psychiatric problems. Her maternal grandfather is diagnosed with a psychotic illness and is on treatment. Furthermore, her paternal grandmother suffers with a mental illness and is on treatment. She also has three paternal aunts who are currently on treatment for mental illness.

\section{Mental State Examination at the time of Admission}

She presented as a slim dishevelled young lady; she was restless with an elated mood. She was laughing inappropriately, singing, and talking to herself. Her speech was incoherent with flight of ideas. There was loosening of associations and she was not able to answer any of the questions she was asked.

It was not possible to identify abnormal beliefs or delusional ideas. Equally she could not tell whether she was experiencing any abnormal perception, but she had hallucinatory attitudes. It was not possible to assess her cognition or her insight. Her Physical examination at the time of admission, as well as laboratory investigations, did not reveal any abnormality.

The provisional diagnosis was schizophreniform disorder, with a differential diagnosis of manic episode associated with psychotic features. She was treated by olanzapine, started with low doses and increased up to 20 $\mathrm{mg}$ daily, in combination with sodium valproate which reached a dose of $1500 \mathrm{mg}$ per day. Patient showed remarkable improvement after one month of treatment and she was given a short home leave with her family, but she did not return. 


\section{Discussion}

Although a case report will not prove a causal relationship, but the presence of several cases reporting the development of psychiatric illnesses following excessive use of energy drinks suggests a possible association $[1,10,11]$. The consumed amounts of energy drinks varied in the different reported cases; Rizkallah and associates reported a case of a psychotic illness after using up to six small cans a day for 1 week [12]. Smaller amounts were also reported; Görgülü and associates reported a case of young male who developed a psychotic illness after he consumed 60-70 energy drinks in a period of one month [11]. In another case, the amount was three cans one week before the onset followed by three more cans three days later [13]. Our patient consumed amounts of energy drinks reached 6 cans of a drink which contains $75 \mathrm{mg}$ of caffeine per can, and that is $450 \mathrm{mg}$ per day. The patient's family reported that she may have used even more than that at times. It is expectable that the amounts of a substance needed to induce a psychiatric illness differ from an individual to another, according to the underlying predisposition. It seems that our patient was predisposed to have a mental illness since she has a significant family history from both paternal and maternal sides.

Duration of energy drink consumption in our case was about four years but increasing in amount, although we couldn't specify the exact duration of the maximum amount use. This increase in amount may be considered as a precipitating factor, since no other obvious biological, psychological, or social factor reported. The published cases varied in the duration of consumption from a few days to several months [10-12,14]

In our case, the clinical presentation was predominated by psychotic features; hallucinations, disorganized speech and abnormal behavior. This is similar to the case reported by Görgülü and associates, the other one re- ported by Hernandez-Huerta and associates $[10,11]$, although several reported cases manifested manic features [12,13].

Our case was not known to have a psychiatric disorder before, and this was also similar to the case reported by Görgülü and associates [11]. This suggests that heavy consumption of energy drinks may be a precipitating factor of the emergence of a new psychotic disorder, as well as reason for relapse in existing disorders, as reported by Rizkallah and associates Machado-Vieira and associates [12,13].

The suggested association between excessive energy drinks and psychotic disorders; i.e. precipitating schizophreniform disorder, may be linked to the high content of caffeine, or the combination between caffeine and other ingredients. Caffeine acts as a competitive antagonist at the adenosine $A_{1}$ and $A_{2 A}$ receptors, and adenosine has an inhibitory effect on dopaminergic neurotransmission. When caffeine block $A_{2 A}$ receptors this may increase dopaminergic activity and when it antagonizes $A_{1}$ receptors this affects the release of neurotransmitters such as glutamate or acetylcholine [9]. Caffeine by these mechanisms enhances dopaminergic effects in the striatum which may lead to exacerbation of psychosis [15]. The other explanation may be that excessive stimulants use leads to sleep dysregulation which may precipitate a psychotic disorder [16]. The energy drink which was used by our patient included the amino acid; taurine which also increases the synthesis and the release of dopamine. This may be due to its effects on chlorine conduction, which in turn facilitate the uptake of dopamine into the synaptic vesicles [17]. By this mechanism, theoretically, taurine may enhance the effect of caffeine in precipitating psychotic features when used excessively. However, studies in the regard are not conclusive.

Other ingredients of the energy drink which was used by our patient do not seem to have any significant psychoactive effects such 
as: carbohydrates, glucuronolactone, pantothenic acid, inositol, and other B vitamins.

Our case suggests an association between excessive use of energy drinks and the emergence of schizophreniform disorder, in the absence of other apparent precipitants. This observation may be of special concern in a community where power drinks consumption is very common while most of psychoactive substances are unavailable or difficult to get. More research is required, with different study designs, to prove and determine the extent of this suggested association.

\section{References}

1. Kelsey D, Berry AJ, Swain RA, Lorenz S. A Case of Psychosis and Renal Failure Associated with Excessive Energy Drink Consumption. Case Rep Psychiatry. 2019;2019:3954161.

2. Reissig CJ, Strain EC, Griffiths RR. Caffeinated energy drinks - a growing problem. Drug Alcohol Depend. 2009;99:1-10.

3. Kim W. Debunking the effects of taurine in Red Bull Energy Drink. Nutrition Bytes. 2003;9.

4. Shao A, Hathcock JN. Risk assessment for the amino acids taurine, L-glutamine and L-arginine. Regul Toxicol Pharmacol. 2008;50:376-99.

5. Perdan Curran C, Marczinski CA. Taurine, caffeine, and energy drinks: Reviewing the risks to the adolescent brain. Birth Defects Res. 2017;109:1640-8.

6. Haskell CF, Kennedy DO, Wesnes KA, Scholey AB. Cognitive and mood improvements of caffeine in habitual consumers and habitual non-consumers of caffeine. Psychopharmacology (Berl). 2005;179:813-25.

7. Kaplan GB, Greenblatt DJ, Ehrenberg BL, Goddard JE, Cotreau MM, Harmatz JS, et al. Dose-dependent pharmacokinetics and psychomotor effects of caffeine in humans. J Clin Pharmacol. 1997;37:693-703.

8. Kendler KS, Myers J, Gardner CO. Caffeine intake, toxicity and dependence and lifetime risk for psychiatric and substance use disorders: an epidemiologic and cotwin control analysis. Psychol Med. 2006;36:1717-25.

9. Lara DR. Caffeine, mental health, and psychiatric disorders. J Alzheimers Dis. 2010;20:239-48.

\section{Ethical Considerations}

Ethical approval was obtained from the ethical committee of Ministry of Health, Taif, Saudi Arabia. Informed consent for publication was signed by the patient's father who was her legal representative, since patient was lacking the capacity of decision making.

\section{Acknowledgements}

None.

\section{Conflict of Interest}

The authors declare no conflict of interests.

10. Hernandez-Huerta D, Martin-Larregola M, GomezArnau J, Correas-Lauffer J, Dolengevich-Segal H. Psychopathology related to energy drinks: a psychosis case report. Case Rep Psychiatry. 2017;2017:5094608.

11. Görgülü Y, Tasdelen Ö, Sönmez MB, Çinar RK. A Case of Acute Psychosis Following Energy Drink Consumption. Noro-Psikyatri Arsivi. 2014;51:79-81.

12. Rizkallah É, Bélanger M, Stavro K, Dussault M, Pampoulova T, Chiasson JP, et al. Could the use of energy drinks induce manic or depressive relapse among abstinent substance use disorder patients with comorbid bipolar spectrum disorder? Bipolar Disord. 2011;13:57880 .

13. Machado-Vieira R, Viale CI, Kapczinski F. Mania associated with an energy drink: the possible role of caffeine, taurine, and inositol. Can J Psychiatry. 2001;46:454-5.

14. Richards G, Smith AP. A review of energy drinks and mental health, with a focus on stress, anxiety, and depression. J Caff Res. 2016;6:49-63.

15. Fisone G, Borgkvist A, Usiello A. Caffeine as a psychomotor stimulant: mechanism of action. Cell Mol Life Sci. 2004;61:857-72.

16. Reeve S, Sheaves B, Freeman D. The role of sleep dysfunction in the occurrence of delusions and hallucinations: A systematic review. Clin Psychol Rev. 2015;42:96115.

17. Kothandam H, Biradugadda P, Mganti B, Keerthi T, Vegunta B, Kopparapu V, et al. Taurine? A key amino acid in the drug discovery? - A review. Asian J Biomed Pharm Sci. 2012;2:21-27. 


\section{Shizofreniformni poremećaj nakon pretjerane konzumacije energetskih pića: prikaz slučaja}

Sažetak - Uvod - Potrošnja energetskih pića svake se godine povećava u cijelom svijetu, posebno među mladima koji traže osjećaj snage i povećanu fizičku i emocionalnu izdržljivost. Energetska pića sadrže kofein koji djeluje stimulativno, ali njegova pretjerana i kronična konzumacija može uzrokovati neželjene učinke; fizičke i psihičke. Postoje neke studije koje su izvijestile o simptomima psihotičnih poremećaja i poremećaja raspoloženja povezanih s pretjeranom uporabom kofeina. Predstavljamo slučaj s jasnim psihotičnim obilježjima kod mlade žene nakon četverogodišnje povijesti konzumiranja velikih količina energetskih pića. Zaključno, ovaj slučaj sugerira povezanost između pretjerane upotrebe energetskih pića i shizofreniformnog poremećaja.

Ključne riječi: energetska pića; psihotični poremećaji; Saudijska Arabija 
